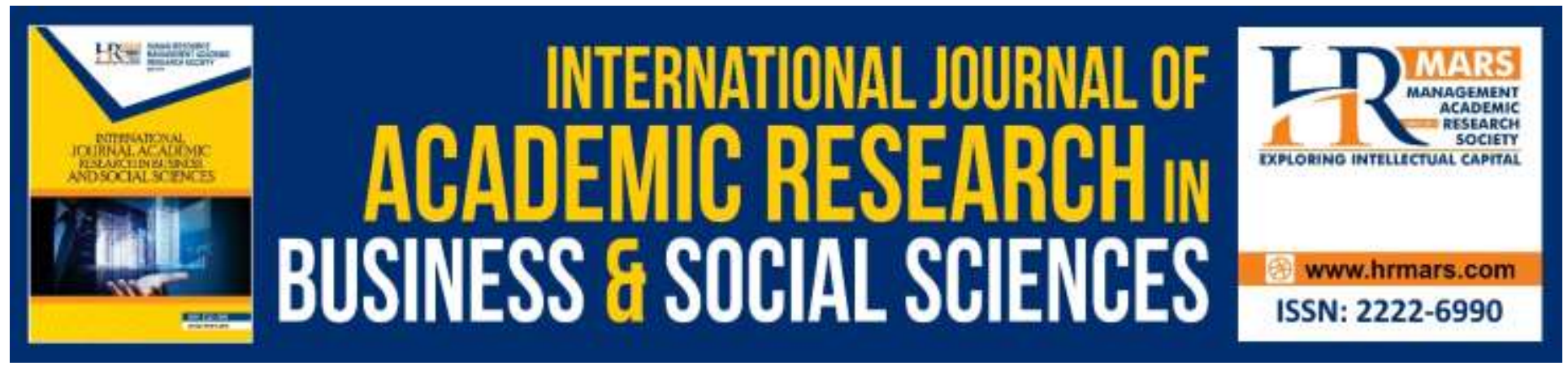

\title{
Using UTAUT Model to Determine Factors Affecting Internet of Things Acceptance in Public Universities
}

\author{
Eman Safar Almetere, Beni Widarman Yus Kelana, Nur Naha Abu Mansor
}

To Link this Article: http://dx.doi.org/10.6007/IJARBSS/v10-i2/6915

DOI:10.6007/IJARBSS/v10-i2/6915

Received: 30 December 2019, Revised: 15 January 2020, Accepted: 30 January 2020

Published Online: 14 February 2020

In-Text Citation: (Almetere et al., 2020)

To Cite this Article: Almetere, E. S., Kelana, B. W. Y., \& Mansor, N. N. A. (2020). Using UTAUT Model to Determine Factors Affecting Internet of Things Acceptance in Public Universities. International Journal of Academic Research in Business and Social Sciences, 10(2), 142-150.

\section{Copyright: (C) 2020 The Author(s)}

Published by Human Resource Management Academic Research Society (www.hrmars.com)

This article is published under the Creative Commons Attribution (CC BY 4.0) license. Anyone may reproduce, distribute, translate and create derivative works of this article (for both commercial and non-commercial purposes), subject to full attribution to the original publication and authors. The full terms of this license may be seen at: http://creativecommons.org/licences/by/4.0/legalcode

Vol. 10, No. 2, 2020, Pg. $142-150$

http://hrmars.com/index.php/pages/detail/IJARBSS

JOURNAL HOMEPAGE

Full Terms \& Conditions of access and use can be found at http://hrmars.com/index.php/pages/detail/publication-ethics 


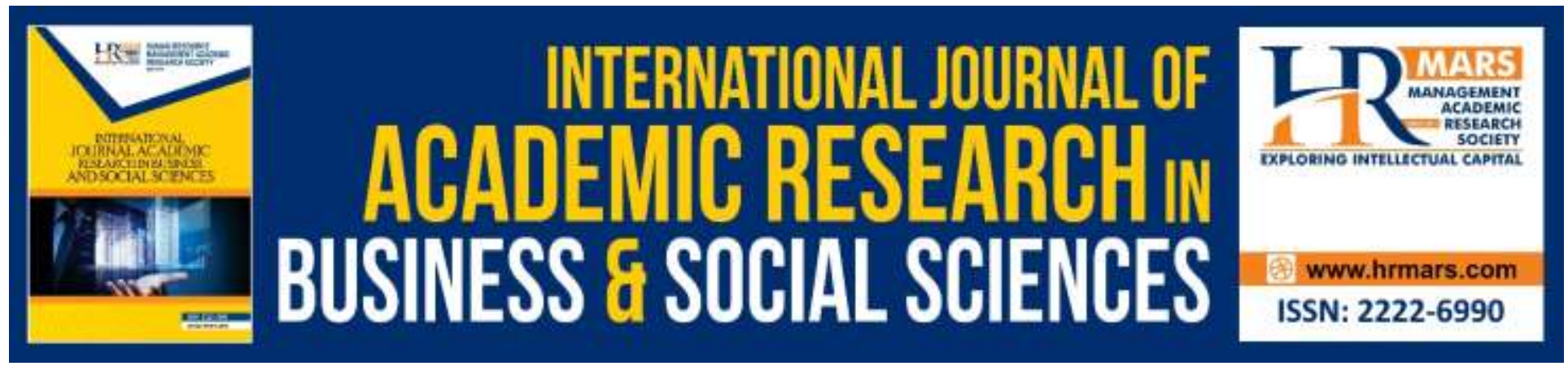

\title{
Using UTAUT Model to Determine Factors Affecting Internet of Things Acceptance in Public Universities
}

\author{
a,bEman Safar Almetere, ${ }^{a}$ Beni Widarman Yus Kelana, aNur Naha \\ Abu Mansor \\ ${ }^{a}$ Azman Hashim International Business School, University Technology Malaysia, Johor, Malaysia \\ ${ }^{b}$ College of Business Administration, Taif University, Taif, Kingdom of Saudi Arabia
}

\begin{abstract}
This article aims to review the influencing factors and their relationships to the adoption of loT technologies in the education domain among undergraduate students in Saudi public universities. The purpose of this study is to propose a framework using UTAUT to increase IoT acceptance. Previous studies found that performance expectancy, effort expectancy, social influence, and facilitating conditions have significant predictors of loT acceptance. However, other studies found that not all UTAUT variables are significant predictors of IoT acceptance such as effort expectancy. There are three research gaps identified through previous studies, field issues, and theory and model. First, there is a lack of studies in consumers' adoption of loT technologies. Second, there is a lack of user acceptance of loT technologies. Third, there is a lack of confident and uncertainty caused by new technologies. A quantitative method approach will be used. The online questionnaire survey well be sent to 300 undergraduate students of the selected public university. The Partial Least Square-Structural Equation Modelling (PLS-SEM) will be used to analyse the collected data.
\end{abstract}

Keywords: Internet of Things - IoT acceptance - UTAUT - Psychological Capital - Technology Adoption

\section{Introduction}

According to Park et al., (2017), internet of things can be described as a network of objects which can be connected through the Internet without human interaction. The traditional Internet provides connections to transfer information between users. The Internet of Things (IoT) means any objects that can communicate and connect to each other through the internet (Biedermann Christopher, 2016; Davies, 2015). . Lohan \& Singh, (2019) explained the benefit of loT in smart home environment and described the loT as a technology that provides autonomous communication functions between different objects using sensors. The loT technology is used in different areas and industries such as, healthcare, smart homes, telecommunication, and transportation (Bandyopadhyay \& Sen, 2011; Gregory, 2015; Khan et al., 2012; Macaulay et al., 2015; Roblek et al., 2016; Weyrich \& Ebert, 2016). Education sector is the most important sector 
that get instantaneous benefits from the technology developments (Agrawal \& Mittal, 2019). Universities that respond to the technology change will have big opportunity to keep growing (Tarhini et al., 2018). Smart technologies are essential learning tools in European countries such as UK, Germany and Italy (Lyapina et al., 2019).

Depends on the latest report from Media Ministry of Saudi Arabia, the market of the internet of things and Machine to Machine communication increases by 2019 and it is expected to reach more than \$16 billion. Saudi Arabia is investing billions of dollars in the domain of smart technologies and internet of things to achieve the 2030 vision especially in loT technologies (AlRuithe et al., 2018). According to Abed et al., (2020) universities are supported by the internet and the adoption of loT enable students to exchange data from different resources such as wearable devices, sensors, and actuators. In education, communication is important for students with the right person in the right time and place (Agrawal \& Mittal, 2019). Students in most universities around the world have already used their wearable devices and smart objects inside their classrooms. Establishing the loT technologies in campuses gives the students opportunities to improve their learning experiences. These technologies are providing smart education to the millennials who became co-creators of knowledge.

\section{Concepts and Definitions}

This study generally discusses the issues relating to the five factors in the framework (performance expectancy, effort expectancy, social influence, facilitating conditions and PsyCap).

\section{Theoretical Background}

\section{The Concept of lot}

A collection of smart objects and devices that are connected and provided with unique identifiers to communicate and transfer data without human or computer interaction (Rosencrance et al., 2014). According to Aldossari and Sidorova (2018), loT is a network of interconnected and uniquely identifiable objects which will lead to dramatic changes in our lives.

\section{Adoption Models}

In the information systems field, there are different developed adoption and acceptance models which came after several efforts during past years. These theories and models have been developed to understand consumer's intention behavior, adoption, and actual usage (Chipeva et al., 2018). The Theory of Reasoned Action is the earliest model in the consumer acceptance research. This model was developed by Ajzen and Fishbein in 1980. The founders of TRA want not only to predict but also to explain and influence the behavior of users through this theory. According to the TRA, the primary determinant of behavior is not the person's attitude towards the behavior, but his or her intention to perform the behavior (Alshehri, 2012). However, TRA has limitation which prevent it from explain other attitude such as irrational decisions or habitual actions. Due to this limitation, Ajzen produced a new extension which is TPB. The Theory of Planned Behavior came to include measures of perceived behavioral control to fix the previous limitation in the TRA. According to Martins \& Oliveira (2014), UTAUT is the most essential and complete model to predict usage intention in technology acceptance and can explain $70 \%$ of the distinction in behavior or intention. According to Chipeva et al. (2018), the unified theory of acceptance and use of technology (UTAUT) was introduced by Venkatesh et al., (2003) to explain 
user intentions to use an information systems and usage behavior. previous acceptance models were merge in an integrated model which is UTAUT. It was built on eight previously developed theories which are TRA, TAM, MM that introduced by Davis et al., (1992) and TPB, MPCU by Thompson et al., (1991), DOI by

(Rogers, 1983), social cognitive theory by Bandura, (1989) and TAM-TPB by Taylor \& Todd, (1995). According to Slade et al., (2015), UTAUT is one of the most important models of technology adoption and has four key constructs which are performance expectancy, effort expectancy, social influence, and facilitating conditions. These factors influence the behavioral;

\begin{tabular}{|l|l|}
\hline $\begin{array}{l}\text { The } \\
\text { predictors }\end{array}$ & Definitions \\
\hline $\begin{array}{l}\text { performance } \\
\text { expectancy }\end{array}$ & $\begin{array}{l}\text { "The degree to which the user expects that using the system will help him } \\
\text { or her to attain gains in job performance" }\end{array}$ \\
\hline $\begin{array}{l}\text { effort } \\
\text { expectancy }\end{array}$ & "The degree of ease associated with the use of the system" \\
\hline $\begin{array}{l}\text { social } \\
\text { influence }\end{array}$ & $\begin{array}{l}\text { "The degree to which an individual perceives that important others believe } \\
\text { he or she should use the new system" }\end{array}$ \\
\hline $\begin{array}{l}\text { facilitating } \\
\text { conditions }\end{array}$ & $\begin{array}{l}\text { "The degree to which an individual perceives that organizational and } \\
\text { technical infrastructure exist to support use of the system" }\end{array}$ \\
\hline $\begin{array}{l}\text { Psychological } \\
\text { Capital }\end{array}$ & $\begin{array}{l}\text { "The positive and developmental state of an individual as characterized by } \\
\text { high self-efficacy, optimism, hope and resiliency (Luthans \& Youssef, } \\
\text { 2004)". }\end{array}$ \\
\hline
\end{tabular}

\section{PYSCAP}

The technology can create an attitude of a lack of confident and uncertainty when the technology is still new in the market such as IoT. In consciences, consumers with less confidence will resist to adopt and work with the new technology (Lee \& Shin, 2019). Some studies examined one of the dimensions (self-efficacy) from PsyCap, but no previous studies talk about the main construct which is PysCap in the technology adoption context. There are several studies investigated the relationship between self-efficacy and the intention to use and they found that there is a positive impact of self-efficacy on the intention to use (Kim et al., 2018). However, no studies examine the relationship between PysCap and the intention to use especially in the loT adoption context. There are many studies found a positive relationship between PsyCap and different attitude and behaviors such as (start-up intention, entrepreneurs' growth intentions, job involvement) and a negative relationship between PsyCap and turnover intention ( Jin, 2017). 


\section{Research Model}

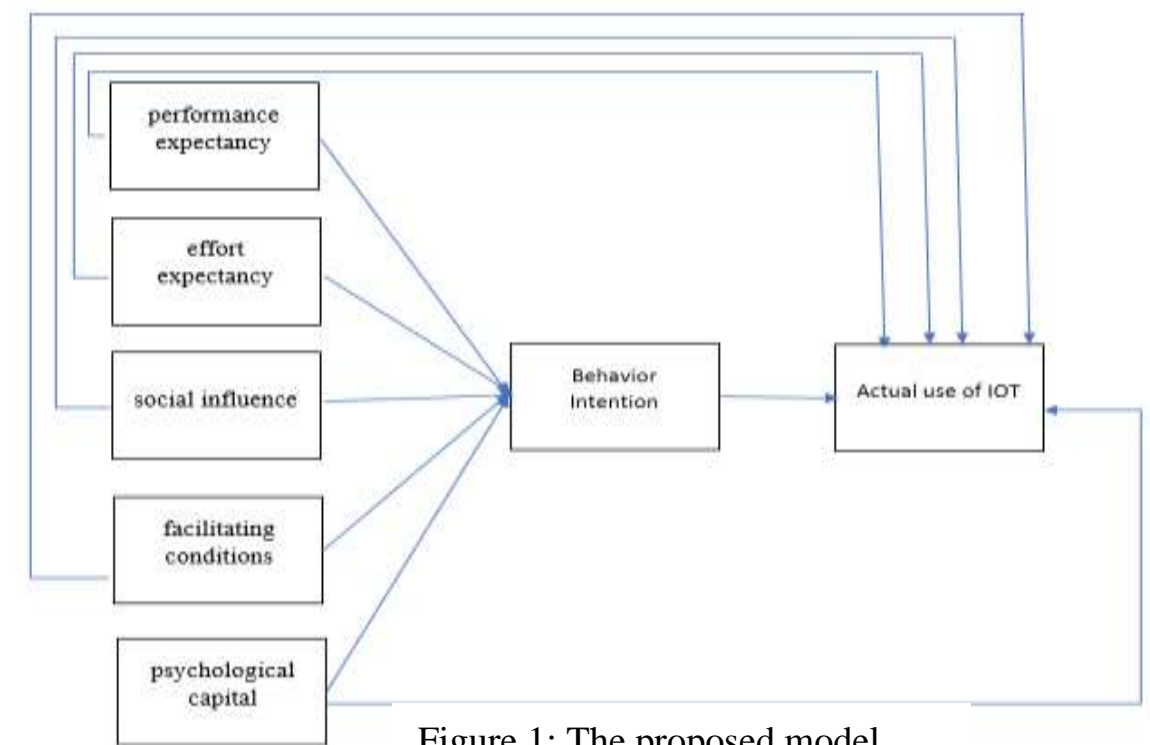

Figure 1: The proposed model

\section{Performance Expectancy}

One of the reliable predictors of behavioral intention in the technology adoption and usage context is performance expectancy (W. Lee \& Shin, 2019). PE is similar to the perceived usefulness of TAM and the relative advantage of IDT (Martins \& Oliveira, 2014). According to Lee \& Shin, (2019), Performance expectancy is described as the degree of user expectation if using a technology will lead to get benefits. In the context of loT, performance expectancy refers to the degree to which students perceive that using the loT technologies will improve their productivity and performance. In other words, consumers will use the technology when they feel that their performance will be improved. For example, students who have Dyslexia will use smart and interactive objects if they feel their auditory and visual skills will be improved.

\section{Effort Expectancy}

Effort expectancy is the degree of ease associated with the use of technology and previous researches have confirmed that EE is a significant predictor of intention to use technologies (Dinev \& Hu, 2007).According to Marr \& Prendergast, (1991)there is a greater chance that technologies will be adopted by users, if these technologies are understandable and clear to use. This statement was supported by Chipeva et al., (2018) in his study in Bulgaria and Portugal. Hence, in the context of loT, students will be able to adopt record class attendance technology if they feel they will spend less effort and can understand the system. Lee \& Shin, (2019), confirmed that the more effort consumers spend to use loT technology, the less likely they will use and adopt this technology. 


\section{Social Influence}

The degree to which an individual perceives that important others believe he or she should use the new system (Venkatesh, 2003). For the purpose of this study, SI means the degree to which the student perceives that important people believe he or she should use the new technology. According to Venkatesh \& Brown (2001), the opinions of student's friends and family members can influence the students to use and adopt new technologies. In the industry of Internet-based banking, social influence has an important and essential role to adopt (Rahi \& Abd. Ghani, 2018; Riquelme \& Rios, 2010; Wang et al., 2015).

\section{Facilitating Conditions}

Venkatesh (2003) has defined facilitating conditions as the degree to which an individual believes that an organizational and technical infrastructure exists to support use of the system. The findings of Venkatesh (2003) and (Handayani \& Sudiana, 2017) confirmed that the facilitating condition has a significant impact on the usage behavior of technology context. According to $\mathrm{Y}$. Wang et al., (2019) some technical support such as computers, internet speed, integration with other systems play important role on the acceptance and use of the technology.

$\mathrm{H}$. Lee , (2009)supported the same statement in the internet banking context and mentioned that user's knowledge, ability, and resources have influence on the use of technology. Technology acceptance is related to have digital skills and if there is a lack of these skills, that would make the students face difficulties to use loT (Bartau-Rojas et al., 2018). However, there are some studies found that facilitating conditions has no impact on usage behavior

\section{Behavioral Intention}

According to Hoque \& Sorwar, (2017) behavior intention means the person willingness to perform a behavior. In other words, behavior intention comes before the usage behavior. The previous information technology acceptance studies discuss the positive relationship between $\mathrm{BI}$ and $A U$ of information technology. Behavioral intention is a mediating variable in this study between the actual usage of IOT and the independent variables which are performance expectancy, effort expectancy, social influence, facilitating conditions, and psychological capital.

\section{Conclusion}

In conclusion, the aim of this study is achieved when the researcher proposed a framework model using UTAUT to increase IoT acceptance in higher education of Saudi Arabia. The framework model developed was based on systematic literature review in order to close and identify the theoretical and practical gaps that would be enhanced and influenced by the developed framework model using UTAUT to increase loT acceptance in higher education of Saudi Arabia. Since this paper is conceptual paper, it gives a significant and overall view about the influencing factors and their relationship to the adoption of loT technology in education domain among undergraduate student in Saudi Public University.

\section{Contribution and Recommendation}

Apparently, the framework model developed based on the past and current studies from prominent scholars does not only limited and practical in higher education in Saudi public 
university but somehow the framework model can be practiced by academicians, practitioners, non-government organization, and ministry of education to implement in their education blueprint to enhance and utilize the technology to the classroom management as well as to the education system.

\section{Limitation}

This study is focusing on one group which is undergraduate students in Saudi public universities. It is recommended in future research to focus on other groups and generations. Future studies should include other nations and expand the boundaries.

\section{Acknowledgment}

First, I would like to thank my supervisors Prof. Nur Naha Abu Mansor and Dr. Beni Widarman Yus Kelana for their guidance, continuous support, and outstanding assistance to do my first conceptual paper. I appreciate the support from Taif University to offer me the opportunity to study in University Technology Malaysia. Finally, warmest appreciation goes to my husband Ahmed for his sustainable support.

\section{References}

Abed, S., Alyahya, N., \& Altameem, A. (2020). lot in education: Its impacts and its future in saudi universities and educational environments. Advances in Intelligent Systems and Computing. https://doi.org/10.1007/978-981-15-0029-9_5

Agrawal, S. R., \& Mittal, D. (2019). Constructive usage of WhatsApp in education sector for strengthening relations. International Journal of Educational Management, 33(5), 954-964. https://doi.org/10.1108/IJEM-07-2018-0205

Aldossari, M. Q., Sidorova, A., \& Aldossari, M. Q. (2018). Consumer Acceptance of Internet of Things ( IoT ): Smart Home Context Consumer Acceptance of Internet of Things ( IoT ): Smart Home Context. Journal of Computer Information Systems, 00(00), 1-11. https://doi.org/10.1080/08874417.2018.1543000

Alshehri, M. A. (2012). Using the UTAUT Model to Determine Factors Affecting Acceptance and Use of E-government Services in the Kingdom of Saudi Arabia Mohammed Abdulrahaman Alshehri Communication Engineering Submitted in fulfilment of the requirements of the degree of Doctor of.

Bandura, A. (1989). Human Agency in Social Cognitive Theory. American Psychologist. https://doi.org/10.1037/0003-066X.44.9.1175

Bandyopadhyay, D., \& Sen, J. (2011). Internet of things: Applications and challenges in technology and standardization. Wireless Personal Communications. https://doi.org/10.1007/s11277011-0288-5

Bartau-Rojas, I., Aierbe-Barandiaran, A., \& Oregui-González, E. (2018). Parental mediation of the Internet use of Primary students: Beliefs, strategies and difficulties. Comunicar. https://doi.org/10.3916/C54-2018-07

Biedermann Christopher, cfbieder@hotmail. (2016). Cybersecurity and the Internet of Things. ZIN - Zagadnienia Informacji Naukowej. Studia Informacyjne.

Chipeva, P., Cruz-jesus, F., Oliveira, T., \& Irani, Z. (2018). Digital divide at individual level : 
INTERNATIONAL JOURNAL OF ACADEMIC RESEARCH IN BUSINESS AND SOCIAL SCIENCES

Vol. 10, No. 2, Feb, 2020, E-ISSN: 2222-6990 @ 2020 HRMARS

Evidence for Eastern and Western European countries. Government Information Quarterly, 35(3), 460-479. https://doi.org/10.1016/j.giq.2018.06.003

Davies, R. (2015). The Internet of Things Opportunities and Challenges. European Parliament Briefing.

Davis, F. D., Bagozzi, R. P., \& Warshaw, P. R. (1992). Extrinsic and Intrinsic Motivation to Use Computers in the Workplace. Journal of Applied Social Psychology. https://doi.org/10.1111/j.1559-1816.1992.tb00945.x

Dinev, T., \& Hu, Q. (2007). The centrality of awareness in the formation of user behavioral intention toward protective information technologies. Journal of the Association for Information Systems. https://doi.org/10.17705/1jais.00133

Gregory, J. (2015). The Internet of Things: Revolutionizing the Retail Industry. In Accenture Strategy.

Handayani, T., \& Sudiana, S. (2017). Analisis Penerapan Model Utaut (Unified Theory Of Acceptance And Use Of Technology) Terhadap Perilaku Pengguna Sistem Informasi (Studi Kasus: Sistem Informasi Akademik Pada Sttnas Yogyakarta). Angkasa: Jurnal IImiah Bidang Teknologi. Https://Doi.Org/10.28989/Angkasa.V7i2.159

Hoque, R., \& Sorwar, G. (2017). Understanding factors influencing the adoption of mHealth by the elderly: An extension of the UTAUT model. International Journal of Medical Informatics. https://doi.org/10.1016/j.ijmedinf.2017.02.002

Khan, R., Khan, S. U., Zaheer, R., \& Khan, S. (2012). Future internet: The internet of things architecture, possible applications and key challenges. Proceedings - 10th International Conference on Frontiers of Information Technology, FIT 2012. https://doi.org/10.1109/FIT.2012.53

Kim, H., Lee, H. J., Cho, H., Kim, E., \& Hwang, J. (2018). Replacing Self-Efficacy in Physical Activity : Unconscious Intervention of the AR Game, Pok é mon GO. https://doi.org/10.3390/su10061971

Lee, H., \& 안현철. (2009). A Study on EC Acceptance of Virtual Community Users. Asia Pacific Journal of Information Systems.

Lee, W., \& Shin, S. (2019). An Empirical Study of Consumer Adoption of Internet of Things Services. INTERNATIONAL JOURNAL OF ENGINEERING AND TECHNOLOGY INNOVATION.

Lohan, V., \& Singh, R. P. (2019). Home Automation Using Internet of Things. In Lecture Notes in Networks and Systems. https://doi.org/10.1007/978-981-13-0277-0_24

Lyapina, I., Sotnikova, E., Lebedeva, O., Makarova, T., \& Skvortsova, N. (2019). Smart technologies: perspectives of usage in higher education. International Journal of Educational Management, 33(3), 454-461. https://doi.org/10.1108/IJEM-08-2018-0257

Macaulay, J., Buckalew, L., \& Chung, G. (2015). Internet of Things in Logistics. DHL Trend Research. Marr, N. E., \& Prendergast, G. P. (1991). Strategies for retailing technologies at maturity: A retail banking case study. Journal of International Consumer Marketing. https://doi.org/10.1300/J046v03n03_05

Park, E., Cho, Y., Han, J., \& Kwon, S. J. (2017). Comprehensive Approaches to User Acceptance of Internet of Things in a Smart Home Environment. IEEE Internet of Things Journal. https://doi.org/10.1109/JloT.2017.2750765 
Rahi, S., \& Abd. Ghani, M. (2018). The role of UTAUT, DOI, perceived technology security and game elements in internet banking adoption. World Journal of Science, Technology and Sustainable Development. https://doi.org/10.1108/wjstsd-05-2018-0040

Roblek, V., Meško, M., \& Krapež, A. (2016). A Complex View of Industry 4.0. SAGE Open. https://doi.org/10.1177/2158244016653987

Rogers, R. W. (1983). Cognitive and physiological processes in fear appeals and attitude change: A revised theory of protection motivation. In Social psychophysiology. A sourcebook.

Rosencrance, L., Shea, S., \& Wigmore, I. (2014). What is internet of things (IoT)? - Definition from Whatls.com. In Tech Target.

Slade, E. L., Dwivedi, Y. K., Piercy, N. C., \& Williams, M. D. (2015). Modeling Consumers' Adoption Intentions of Remote Mobile Payments in the United Kingdom: Extending UTAUT with Innovativeness, Risk, and Trust. Psychology and Marketing. https://doi.org/10.1002/mar.20823

Tarhini, A., Tarhini, J., \& Tarhini, A. (2018). Information technology adoption and implementation in higher education Evidence from a case study in Lebanon. International Journal of Educational Management,. https://doi.org/10.1108/IJEM-04-2018-0144

Taylor, S., \& Todd, P. A. (1995). Understanding information technology usage: A test of competing models. Information Systems Research. https://doi.org/10.1287/isre.6.2.144

Venkatesh, V., Morris, M., Davis, G., \& Davis, F. (2003). TECHNOLOGY ACCEPTANCE MODEL Research. MIS Quarterly.

Wang, S. W., Ngamsiriudom, W., \& Hsieh, C. H. (2015). Trust disposition, trust antecedents, trust, and behavioral intention. Service Industries Journal. https://doi.org/10.1080/02642069.2015.1047827

Wang, Y., Han, J. H., \& Beynon-Davies, P. (2019). Understanding blockchain technology for future supply chains: a systematic literature review and research agenda. In Supply Chain Management. https://doi.org/10.1108/SCM-03-2018-0148

Weyrich, M., \& Ebert, C. (2016). Reference architectures for the internet of things. IEEE Software. https://doi.org/10.1109/MS.2016.20 